\title{
Analysis Factor Influence Poverty on Bengkulu
}

\author{
Elida Madona Siburian* \\ Economic department of Universitas Negeri Medan \\ North Sumatera \\ madonaelida@gmail.com \\ M. Fitri Rahmadana ${ }^{2}$ \\ Management Studies of Universitas Negeri Medan \\ North Sumatera \\ mufitra140977@yahoo.com²
}

\begin{abstract}
This research aimed to analyze the partially and together effect of population, education and unemployment on poverty in Bengkulu Province. This research is a kind of association explanation research and using multiple regression analysis. The dependent variable in this research is poverty, while the total population, education, and unemployment as the independent variable. Regression results indicate that the variables of population and education do not effect on poverty. the unemployment variables effect to the poverty. For $F$ test considers the three independent variables collectively effect to the dependent variable (poverty).
\end{abstract}

Keywords-poverty, total population, education, and unemployment.

\section{INTRODUCTION}

The developing countries in the world including Indonesia faced with a problem that is poverty. According to the economist (in arsyad, 2010) poverty in indonesia are multi dimensional. Poverty is multi dimensional can be seen from various aspects. The primary aspect in the form of poor assets, political, and social organization of knowledge as well as skills are low. While the secondary aspect in the form of poor social networks, financial resources and information. The number of poor population between provinces in Indonesia is different, the highlights are the number of poor population in the province of bengkulu are quite high compared to other provinces in sumatra. Where as each of the provinces has access and facilities to fulfill the necessities of life. Poverty in between provinces in sumatra is also different, following the data showing the number of poor population on the island of Sumatra. Bengkulu province ranks first. The provincial government of bengkulu province has set policy through a variety of programs to reduce poverty levels. There are two how to do for tackling and alleviating poverty, that reduces the income of poor households and nearly destitute.

To reduce the burden of the government's efforts to help reduce the costs of health care, as well as to clean water, roads and so on. In order to increase the income of poor households as well as almost poor government economic earnings do trainings, business economics, a stimulant working capital / business (cooperative women), market village, and local economic empowerment activities as well as increased production through appropriate technology. However, poverty is still a problem for the goverment of the province of bengkulu, the government should not only look at the terms of the micro course in term of macro, ranging from population, education and unemployment.

The total population of the province of bengkulu each year continues to grow. Malthusian theory in skousen (2009: 85) essentially states that the resources of the earth could not compensate for the needs of the population continue to grow, as a result of human needs that are not limited to is inversely proportional to the amount of natural resources used as a means of satisfying human needs are limited, this will encompass the approach of the poverty line because of the competition tight enough in the fulfillment of the requirement.

World education especially in bengkulu province over the age of 15 still experience illiteracy, in the current era of globalization of education is one of the milestones in the get a job. According to mulyadi (2008) education function of preparing one of the inputs in the production process. This will encourage an increase in the expected output of the boils down to the welfare of the population. At this time the land of the job people have many replaceable by machines. According to sukirno (2006) the jobs added was lower than the increase of the workforce will lead to a lot of labor is not getting the job done. The incident will add to the list of poor residents in bengkulu province. (1) is partially influence on population, unemployment and education againts poverty in bengkulu, (2) is there any influence together of the population, unemployment and education againts poverty in the Bengkulu province.

\section{LITERATURE REVIEW}

\section{A. Poverty}

Poverty is often understood as a state of lack of money and goods to ensure survival. According to the BPS (2012), poverty is seen as the inability of the economy to meet the basic needs of good and food that is not measured in terms of expenditure. According to ravallion (2001) (in arsyad, 2010) 
poverty is "starving, homeless, when the pain did not have funds for medical treatment". From the above two definitions of poverty can be defined as an inability to meet a variety of needs such as food, housing, clothing, education, health, and so on.

Factory cause of poverty, according to paul spicker (wijayanto, 2010) causes of poverty can be divided into four mazbab, are individual explanation, familial explanation, subcultural explanation, structural explanation Based on the above description, it can be concluded that the causes of poverty can come from yourself (natural factors), and from the surrounding environment (non natural factors).

\section{B. Population}

Central bureau of statistics indonesia (2016) lays out "the population is all of the people who live in the geographical area of the republic of indonesia for 6 months or more who is domiciled in less than 6 months but aims to settle". While according to said (2001), the population is "the number of people who live in a region at any given time and the result of demographic processes is fertility, mortality, and migration". From both of them can be inferred that the population is a collection of human beings who are subject to change at any time due to the process of birth, death, and the shift from one region to another.

\section{Education}

According to the central bureau of statistics indonesia (2011), education is the teaching and learning activities at all levels of both formal and informal. According to purwanto (2010) education was guidance / help given to the children by a parent of adult children in order deliberately to adulthood. Education is a conscious effort and planned to develop a religious, spiritual power of self-control, personality, intelligence noble morals, as well as the necessary skills people, the community, the nation and the state (UU No. 20 of the year 2003). From a variety of the above it can be concluded that the sense of education is the guidance provided by the adult to child development to reach his duties of his own life without relying on others.

\section{Unemployment}

According to soekirno (2006) unemployment is "someone who is already classified in the work force who are actively job are hardly be at a certain level, but are unable to obtain the desired job". Irawan and suparmoko (2002) defines unemployment is "those who are in the age of the work force and is looking for a job at the prevailing wage rate. While according to suparmoko (2007) unemployment is "an inability of the labor force to get a job as they need or they want". The third opinion from above can concluded that unemployment is a labor force that is actively looking for a job that suits your skills and education, but because of lack of jobs they haven't got in accordance with the job they want.

\section{RESEARCH METHOD}

The data used to support the research is secondary data from central bureau statistics of bengkulu province from years 1999-2015. The research method used linear regression model approach through multiple to estimate the influence of several factors that impact poverty such as Population, education and unemployment in the year 1999-2015.

Based on observation data simulation and regression results it was decided againts the equations are used:

$$
\mathrm{Y}=\mathrm{a}+\mathrm{b} 1 \mathrm{X} 1+\mathrm{b} 2 \mathrm{X} 2+\mathrm{b} 3 \mathrm{X} 3
$$

Information :

$$
\begin{array}{ll}
\mathrm{Y} & =\text { Poverty } \\
\mathrm{X} 1 & =\text { Total population } \\
\mathrm{X} 2 & =\text { Education } \\
\mathrm{X} 3 & =\text { Unemployment } \\
\mathrm{a} & =\text { constanta }
\end{array}
$$

b1 b2 b3 = Coefision Regression

\section{FINDINGS}

\section{A. Result and Discusion}

TABLE I

\begin{tabular}{|c|c|c|c|c|c|}
\hline \multirow[t]{2}{*}{ Model } & \multicolumn{2}{|c|}{$\begin{array}{l}\text { Unstandardized } \\
\text { Coefficients }\end{array}$} & \multirow{2}{*}{\begin{tabular}{|l}
$\begin{array}{l}\text { Standardized } \\
\text { Coefficients }\end{array}$ \\
Beta
\end{tabular}} & \multirow[t]{2}{*}{$\mathrm{t}$} & \multirow[t]{2}{*}{ Sig. } \\
\hline & B & Std. Error & & & \\
\hline $\begin{array}{c}\text { Total } \\
\text { Population }\end{array}$ & -36.335 & 96.063 & & -.378 & .712 \\
\hline 1 Education & .562 & 1.301 & .125 & .432 & .673 \\
\hline $\begin{array}{c}\text { Unemployme } \\
\text { nt }\end{array}$ & .833 & .293 & .822 & 2.840 & .015 \\
\hline
\end{tabular}

ANOVA $^{\mathrm{a}}$

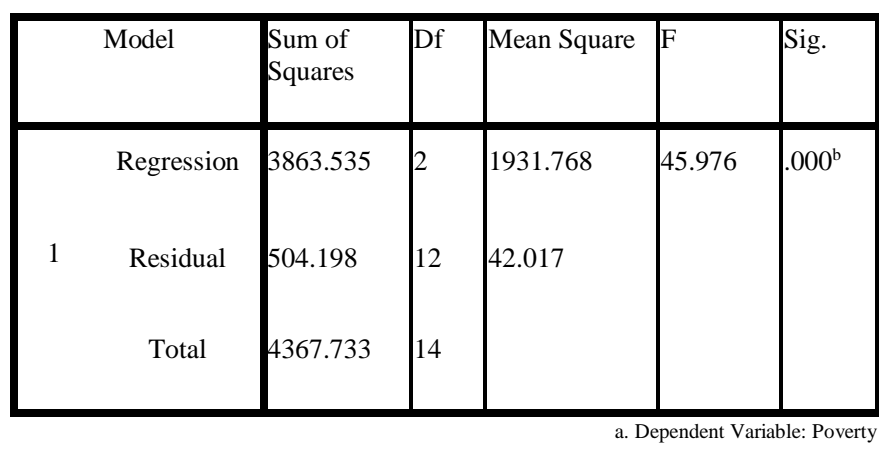

b. Predictors: (Constant), total population, education, unemployment.

TABLE II

Coefficients $^{\mathrm{a}}$ 
TABLE III

Model Summary

\begin{tabular}{|c|l|l|l|l|}
\hline Model & R & R Square & $\begin{array}{l}\text { Adjusted } \\
\text { R Square }\end{array}$ & Std. Error of the Estimate \\
\hline 1 & $.941^{\mathrm{a}}$ & .885 & .865 & 6.48201 \\
\hline
\end{tabular}

a. Predictors: (Constant), Total Population, Education, Unemployment

The result of multiple regression analysis calculation indicates that the population has no effect on the population. This is the result of the theory in this research. According to malthusian theory in skousen (2009: 85) population tends to grow according to the geometric progression (geometric), while food production (natural resources) tend to grow according to the series of the count (arithmetic). As a result of the inefficient provision between the earth resources and the need for a growing population. In other words if development resources can not support the development of population it will cause poverty. Furthermore, according to coale-hoover in mulyadi (2008) that population growth as a bully's development. This is due to the success of the family planning program $(\mathrm{KB})$ appear from the results of population census 2000 , so the distribution of population is more dominated by the productive age or population pyramid-shaped like barrels upside down. The shape of the population pyramid about population census 2000 , inflating the population but little bit shifte dip wards. This indicates that the median age of bengkulu province results of population census 2010 is older than population census 2000. The productive age population that dominates the population of productive employment opportunities for improving the well-being of living is still wide open.

Education in this research is focused on the population who experienced the illiteracy. The results of multiple regression analysis show that education has no effect on poverty. The results of this study are similar to the todaro (2006: 434) states that education is a fundamental development goal. Furthermore, according to the world bank in nirvana (2013) education is one of the most powerful instruments for reducing poverty. Education that is focused on the numbers of illiterate does not affect poverty because of the average resident of bengkulu province that illiterate the age of the countryside. From 72,31 percent inhabitants of the province of bengkulu aged 15 years and above who are having illitaracy are women. The rate of labor force participation is closely related to levels of education that will be higher. This indicates that higher the educational level to the end of the world is open. In fact, the data shows about population census 2010 show that the rate of labour participation of countryside is higher than the level for the whole urban the rate of labour force participation of education to end.

Unemployment would cause economic and social issues, and result in the absence of an income that can eventually lead to prosperity would further slump. Declining well-being due to idle, can result in opportunities are stuck in poverty. This is in accordance with the opinion of arsyad (2010: 359) stating that there is a close relationship between the level of unemployment, once the extent of poverty, income distribution and uneven. The high unemployment figures, potentially reducing the economic opportunism in regional productivity increases, and reflects the greater social burden to the community. Thus the public will slowly pushed on the poor population groups. Permana and arianti (2012) research also points that unemployment is directly influential and significant impact on poverty. Guidelines used as references is the opinion of sukirno (2004) stating that the ill effects of unemployment is reducing the revenues of the community that ultimately reduces the level of prosperity that reached a person. Many empirical studies indicate that the main source of poverty is unemployment.

A growing decline in welfare of societies for the unemployed will the increase of the chances of them trapped in poverty because it does not have an income. When unemployment in an area is very bad political and social chaos, always apply and cause ill effects for the well-being of the community and the prospects for economic development in the long run. In contrast to research done Amalia (2012), that unemployment has no effect of high levels of family income so that it is able to sustain the cost of living for a job that is true corrects to the field as well as the desired income level only, and do not want to look for a job that is not in accordance with the field and the level of wages is expected.

To know the influence together population, education, and unemployment on poverty in bengkulu province used $\mathrm{f}$ test. $\mathrm{F}$ test results indicate there is influence of population, education, and unemployment on poverty in the Bengkulu province. Development aimed at achieving the prosperity and welfare of the community. Along with the various endeavors of the program going on ditortion of one development poverty. Poverty is a complex problem, the occurrence of poverty can be affected by population, education, and unemployment. A large population is indeed a great potential. According to smith's population growth was able to encourage economic growth. The population is seen from the side of employment is the supply to the labor market in a region. If the population growth and the quality of human resources received no attention from the government, can result in a rate of uncontrolled population growth. It is worried about increased the number of unemployment and increase the number of poor population.

A large of total population must be balanced with adequate quality of education, to create the resources apparent quality. New growth theory emphasizes the development of human capital and encourages research and development to enhance human productivity. According to Todaro (2006) education is a fundamental development goal. Human resources quality is the most important asset for the development in various aspects of public life. quality human resources is the man who has the intellectual qualities, character, moral and physical. Reality can be seen by improving the quality of human resources is shown with the knowledge and skills of a person. The higher level of education a person, then the knowledge and expertise will increase the productivity of work. By 
having a qualified human resources then it can compete in the international competition is increasing tight.

At a time of increasingly tight competition in employment then the primary indicator is seen is the experience and education. When the top priority is education and the qulity of education does not correspond to the expected work request the number of requests that occured then work decreased, so that more and more unemployment. Not only the factor of education, unemplyoment occurs because the mindset in the world governing agencies, while in the second line of the sector the available job opportunities are still very limited. The number of high unemployment will affect development. The unemployment rate can describe the ability of a structure of economy in providing jobs, which is very influent in the equitable ditribution of income and social welfare. This refers to the opinion of arsyad (2010) there is a close relationship between high rates of unemployment once, the extent of poverty, income distribution and uneven.

TABLE IV

The percentage of the workforce according to the highest education and types of areas in bengkulu province the year 2010

\begin{tabular}{|c|c|c|}
\hline level of Education & Urban & Rural \\
\hline No School & 6,10 & 18,59 \\
\hline Did not finish elementary school & 5,23 & 8,54 \\
\hline Primary School & 27,32 & 41,18 \\
\hline Junior high school & 21,78 & 18,42 \\
\hline Senior high school & 30,59 & 11,10 \\
\hline diploma & 2,31 & 0,76 \\
\hline Collage & 6,67 & 1,42 \\
\hline \multicolumn{2}{|c|}{ Source: central bureau statistics of bengkulu Province 2016 } \\
\hline
\end{tabular}

\section{B. Conclusion}

Bengkulu more dominated by age-age of productive so that employment opportunities for improve the well-being of living is still wide open.

Education has no effect against poverty, because the average resident of bengkulu province is illiterate the age of youth is not educated, and most happen in rural areas. A resident of bengkulu province over the age of 15 who is experiencing average illiterate are woman.

The results of this research show that unemployment affects poverty. This means that when unemployment is high then the poverty is also high

Population, education, unemployment are significant effects on poverty. A large population coupled with the quality of human resources quality, then the higher productivity of labor so as to reduce poverty.

\section{Suggestion}

Based on the conclusions above, then the advice of the agriculture to repeat the triumph of the agricultural sector (informal sector) that be self-sufficient in food, then it will be good if processing, empowerment, and training handed back on without making it easier for farmers in getting everything it needs.

Through the Department of Cooperatives and small medium enterprises. Cooperatives and small medium enterprises (informal sector) is an independent business that is already proven to be able to survive on the crisis and contributed to the economy of the country. To restore the position of the cooperatives in place and fosters trust in the cooperative society will then need for the filter in the establishment of cooperatives and small medium enterprises by providing capital loans with low interest rates by the Government or through cooperative effort that is run though cooperative.

BKKBN pay more attention to the rate of population growth in the village, so the main focus of the groundbreaking $\mathrm{KB}$ is better done in the village. For example, give responsibility for the village midwives to become a family planning project.

The education office not only focuses on formal education, because non-formal education it also can provide a productive workforce so that government assistance is provided as part of the development of non-formal education. of creativity (sewing) able to provide a productive workforce for the development of non-formal education.

\section{REFERENCES}

[1] Amalia, Fitri, "The influence of education, unemployment and inflation on poverty rate in eastern indonesia (ITC)", 2001-2010.

[2] Arsyad, Lincolin, "Economic development", Yogyakarta: UPP STIM YKPN, 2010.

[3] Clair and Pamela, "Does the heavily indebted poor countries (HIPC) initiative realize its goals of poverty alleviation?", Journal of poverty alleviation and international development, "In Press", 2014.

[4] Ihsan, Fuad, "Basic educational components MKDK, Jakarta: PT Rineka Copyright, 2008.

[5] Irawan and Suparmoko, The economics of development, the fifth edition", BPFE-Yogyakarta: Yogyakarta, 2002.

[6] Lipsey, Richard G et al, "Introduction to macro-economics", the eighth edition of Erlangga, Jakarta, 2006.

[7] Milu and Phillip, "Household incomes and poverty dynamics in rural kenya : a panel data analysis", Journal of poverty alleviation and international development, "In Press", 2014.

[8] Mohammed Selemana, "Measuring multidimensional poverty in ghana"s east gonja district", Journal of poverty alleviation and international development, "In Press", 2016.

[9] Mulyadi, "The economics of human resources in a perspective of development", Jakarta: Eagle Press, 2008

[10] Skousen, Mark, "The history of the economic thought of the Maestro", Jakarta: Prenada, 2009.

[11] Sukirno, among other, "Introduction to theory of Macroeconomics. Jakarta: PT. Raja Grafindo persada, 2004.

[12] the Central Bureau of statistics, "Analysis of Draft Macro-Economic Performance of Bengkulu Province year 2008" North Sumatra, Indonesia: BPS, 2008

[13] --- "Analysis socio-economic indicators of bengkulu province 2003-2007” North Sumatera, Indonesia: BPS, 2007

[14] The Department of National Education: the ACT Number 20 year 2003 About Sisdiknas, Jakarta, 2003.

[15] Todaro, michael p, "Economic development", Jakarta: eason, 2006. 
